\title{
The bee genus Caenaugochlora (Hymenoptera, Apoidea) and its constituent subgenera, with new species of Caenaugochlora s.str. from Ecuador
}

\author{
Rodrigo B. Gonçalves ${ }^{1, \dagger}$, Michael S. Engel ${ }^{2,3, \neq}$ \\ I Museu de Zoologia da Universidade de São Paulo, Av. Nazaré 481, 04263-000, São Paulo, SP, Brazil 2 Di- \\ vision of Entomology (Paleoentomology), Natural History Museum, and Department of Ecology \& Evolutionary \\ Biology, 1501 Crestline Drive - Suite 140, University of Kansas, Lawrence, Kansas 66049-2811, USA 3 \\ Division of Invertebrate Zoology, American Museum of Natural History, Central Park West at 79th Street, New \\ York, New York 10024-5192, USA \\ † urn:lsid:zoobank.org:author:CD9DE502-CBB7-485F-87E2-7677B94FA083 \\ † urn:lsid:zoobank.org:author:3714A7FF-E19E-495A-AAF9-98D2F597B757 \\ Corresponding authors: Rodrigo B. Gonçalves (goncalvesrb@gmail.com), Michael S. Engel (msengel@ku.edu) \\ Academic editor: Michael Ohl| Received 9 December 2009 | Accepted 23 January 2010 | Published 25 February 2010 \\ urn:lsid:zoobank.org:pub:9C249E86-0DB8-480F-B54E-3F0704A963D7 \\ Citation: Gonçalves RB, Engel MS (2010) The bee genus Caenaugochlora (Hymenoptera, Apoidea) and its constituent \\ subgenera, with new species of Caenaugochlora s.str. from Ecuador. ZooKeys 37: 69-80. doi: 10.3897/zookeys.37.366
}

\begin{abstract}
Two new species of Caenaugochlora Michener are described and figured from Ecuador. Caenaugochlora quichua sp. n. and C. bennetti sp. n. are both remarkable for the presence of carinate preoccipital carinae, setose compound eyes, strongly rimmed metabasitibial plate, normally pectinate inner metatibial spur, metapostnotal striae not reaching the apical margin, and the male fourth metasomal sterna with lateral projections. The combination of these features intermingle attributes of the presently recognized subgenera, while others are unique to the genus as a whole. A revised diagnosis is provided for the genus and its two subgenera, with Caenaugochlora s.str. accommodating C. bennetti and C. quichua, and brief comments made regarding the implications of the characters exhibited by the aforementioned species.
\end{abstract}

\section{Keywords}

Hymenoptera, Apoidea, Anthophila, Augochlorini, Caenaugochlora, taxonomy, Ecuador, Halictidae 


\section{Introduction}

Caenaugochlora was proposed by Michener (1954) for Augochlora-like bees with setose compound eyes, as a replacement for Caenohalictus Cameron which had been misapplied at the time various unrelated bees. Michener based his description on a pectinate inner metatibial spur, reduced preoccipital carina, setose compound eyes, and the fourth metasomal sternum with a medioapical notch bordered by areas with specialized setae. At that time Michener (op. cit.) included Pseudaugochlora Michener as a second subgenus but subsequent authors have considered the group as a separate genus (Eickwort 1969; Engel 2000; Michener 2007; vide Almeida 2008, for a comments regarding Pseudaugochlora). Later, Eickwort (1969) described the subgenus, Ctenaugochlora, to include a distinctive species related to Caenaugochlora. He considered Caenaugochlora proper to include those species with the fourth metasomal sternum with one or two median patches of setae on raised tubercles to either side of a medioapical depression, while Ctenaugochlora was described for a species with a densely pectinate inner metatibial spur, a metabasitibial plate only defined posteriorly, and the male fourth metasomal sternum with a V-shaped patch of setae bordering a slight median depression. Engel (2000) updated the number of species of both genera and diagnosed the subgenera of Caenaugochlora based on the same characters.

Moure (2007) listed 15 described species for Caenangochlora s.str., while Engel $(2007,2009 a)$ added two additional species and removed another to elsewhere in the Augochlorini. Species of Caenangochlora s.str. described to date occur in México to Ecuador (Table 1), although unstudied and undetermined material is known from Nicaragua, Venezuela, and Trinidad. Ctenaugochlora presently includes five species in Costa Rica and Panamá, with a single putative record from Bolivia (Engel and Gonçalves, in press). Nothing is known about their natural history except for the ground-nesting biology and semisocial behavior of $C$. costaricensis described by Michener and Kerfoot (1967).

The purpose of the present study is to describe two new species of Caenaugochlora s.str. from Ecuador which have diagnostic characteristics of both subgenera as currently recognized and share a peculiar structure of the fourth metasomal sternum, different from that of other Caenaugochlora s.l. Both species may prove critical for illuminating the phylogenetic placement of Caenaugochlora s.l. among Augochlorini.

\section{Methods}

Material considered herein is deposited in the following institutions: Museu de Zoologia da Universidade de São Paulo, São Paulo, Brazil (MZSP) and Snow Entomological Collection, Division of Entomology, University of Kansas Natural History Museum, Lawrence, Kansas, USA (SEMC). Quotation marks surround exact transcriptions of individual labels, while the reverse solidus $(\backslash)$ indicates different lines on the same la- 
Table I. Knwon records for Caenaugochlora s.str. species.

\begin{tabular}{|c|c|c|c|c|c|c|c|}
\hline \multirow{2}{*}{ Species } & \multicolumn{7}{|c|}{ Known records } \\
\hline & México & Guatemala & Honduras & Costa Rica & Panamá & Colombia & Ecuador \\
\hline C. aequilanx (Vachal) & $\mathrm{X}$ & & & & & & \\
\hline C. chaetops (Vachal) & $\mathrm{X}$ & & & & & & \\
\hline C. cupriventris (Vachal) & $\mathrm{X}$ & & & & & & \\
\hline C. Alagrans (Vachal) & $\mathrm{X}$ & & & & & & \\
\hline C. fulgur (Vachal) & $\mathrm{X}$ & & & & & & \\
\hline C. inermis (Vachal) & $\mathrm{X}$ & & & & & & \\
\hline C. tonsilis (Vachal) & $\mathrm{X}$ & & $\mathrm{X}$ & & & & \\
\hline C. amatitlana (Cockerell) & & $\mathrm{X}$ & $\mathrm{X}$ & & & & \\
\hline C. gemmella (Cockerell) & & $\mathrm{X}$ & & $\mathrm{X}$ & & & \\
\hline C. wilmattae (Cockerell) & & $\mathrm{X}$ & $\mathrm{X}$ & & & & \\
\hline C. cyanella Engel & & & $\mathrm{X}$ & & & & \\
\hline C. costaricensis (Friese) & & & & $\mathrm{X}$ & & & \\
\hline C. elisabethae Engel & & & & $\mathrm{X}$ & $\mathrm{X}$ & & \\
\hline C. macswaini Michener & & & & & $\mathrm{X}$ & & \\
\hline C. jeffreyi Engel & & & & & & $\mathrm{X}$ & \\
\hline C. silvicola Engel & & & & & & & $\mathrm{X}$ \\
\hline C. bennetti sp. n. & & & & & & & $\mathrm{X}$ \\
\hline C. quichua sp. n. & & & & & & & $\mathrm{X}$ \\
\hline
\end{tabular}

bel. Morphological terminology follows that of Eickwort (1969) and Michener (2007) except in that, following Engel (2001), we use "mesoscutum" in place of "scutum" and a revised venational nomenclature. In addition, we here use "metapostnotum" for the "basal area of the propodeum" and following Engel (2009b) we refer to the "teeth" of the pectinate spurs as "branches". Species descriptions loosely follow those of Engel $(1997,2007)$, while generic and subgeneric diagnoses and descriptions follow that of Engel (2000), with new interpretations of particular characters as revealed by the new species described herein highlighted in bold.

\section{Systematics}

\section{Genus Caenaugochlora Michener}

Diagnosis. Most species of Caenaugochlora are similar in general appearance to those of the genus Pseudaugochlora; however, the latter genus has a strong ridge on the vertex and a pointed galeal apex. From the related genus Augochloropsis, Caenaugochlora differs in the absence of a notch on the tegula, the non-lamellate pronotal dorsal ridge, and the orthogonal epistomal sulcus. 
Description. Female: Mandible with subapical tooth variously defined. Labral distal process narrowly triangular; basal elevation orbicular; teeth absent. Prementum not greatly elongate. Galeal apex rounded; galeal comb absent; galeal base extending to stipital base. Hypostomal ridge carinate; anterior angle rounded. Length of malar space less than basal mandibular width except in C. silvicola malar space as long as basal mandibular width. Epistomal sulcus orthogonal. Ocelli not greatly enlarged; ocellar furrow absent. Vertex not expanded or ridged behind ocelli. Preoccipital ridge sharply angled or carinate. Pronotal dorsal ridge carinate; lateral ridge rounded to carinate. Mesoscutal anterior border rounded; mesoscutal lip rounded. Tegula oval. Probasitarsal brush present; inner metatibial spur pectinate. Apex of marginal cell truncate; distal hamuli with irregular spacing pattern. Propodeal pit narrow. Male: Mandible simple. Labrum with distal process narrowly triangular as in the female; basal area notched. Antennae extending back to mesoscutellum; second flagellomere about as long as first flagellomere. Inner metatibial spur serrate. Metasoma oval. Apical margin of metasomal sternum III variable, straight, arcuate, or notched; apical margin of metasomal sternum IV variable, lateral projections present or not; apical margins of metasomal sterna V and VI emarginate; apical margin of metasomal sternum VII with median projection; spiculum narrow; proctiger unmodified. Gonobasal bridge narrow; dorsal lobes weak; basal process of gonostylus and parapenial lobe present or absent; dorsal process partly membranous; ventral surface of penis valve with prong.

\section{Subgenus Caenaugochlora Michener}

Caenaugochlora Michener, 1954: 76. Type species: Caenaugochlora macswaini Michener, 1954, original designation.

Diagnosis. Caenaugochlora s.str. is distinguished from Ctenaugochlora by the normal pectination of the inner metatibial spur (with less than 10 long branches), frequent presence of long compound eye setae, strong anterior border of the metabasitibial plate, and metapostnotal striae not reaching to the apical margin.

Description. As for the genus with the following additions: Female: Compound eyes usually with long setae. Preoccipital ridge carinate (as in C. macswaini) or sharply angled (most species). Pronotal lateral angle usually produced, angle slightly acute to obtuse. Metabasitibial plate bordered anteriorly and posteriorly; inner metatibial spur pectinate. Metapostnotum with basal striae, not reaching apical margin. Male: Apical margin of metasomal sternum III variable, straight, arcuate, or notched; apical margin of metasomal sternum IV variable, straight to notched with some apical setal patches surrounding medial notch; lateral projections present or not; apical margin of metasomal sternum VIII with median projection, sometimes bilobed at apex. Volsella indented on inner margin (except in C. bennetti sp. n.).

Distribution. Species of Caenaugochlora s.str. occurs from México to Ecuador, including Venezuela and Trinidad. 


\section{Caenaugochlora (Caenaugochlora) bennetti, sp. $\mathrm{n}$.} urn:lsid:zoobank.org:act:FB2CE682-B684-4BFF-BF1C-F27ADECB83BD Figs 1, 3, 5, 7, 9, 11, 13

Holotype. Õ, "Ecuador:\} 3 \text { mi. W. of Paute, Azuay } \backslash 1 7 - \text { II-1965" "E.I. Schlinger \& } E.S. Ross $\$ collectors" (SEMC).

Paratypes. $3 \hat{\partial} \hat{\partial}, 1 q$, with same label data as that of holotype; $2 \hat{\jmath}, 1 q$ (SEMC) and 1ð, 1 ㅇ (MZSP) labeled, "Ecuador, Cuencal Azuay Prov.l III-13-1965" "L.E. Penal collector".

Diagnosis. Both sexes with preoccipital ridge carinate; female metabasitibial plate well rimmed; female metapostnotum with striations weakly reaching posterior margin where they become difficult to discern among strongly granular integument (Fig. 3); male face almost straight above antennal alveoli, setae on this portion long and weakly branched; apical margin of metasomal sternum III not notched; apical margin of metasomal sternum IV straight, subapical margin with a distinct median patch of erect setae, length of lateral projections less than sternum length (Fig. 7).

Description. Female: Total body length $7.0 \mathrm{~mm}$; forewing length $5.2 \mathrm{~mm}$; distance between compound eye notches $1.3 \mathrm{~mm}$; maximum head length $1.7 \mathrm{~mm}$; intertegular distance $1.33 \mathrm{~mm}$. Head slightly triangular (Fig. 1); mandible with weak subapical tooth; malar space very short, less than basal mandibular width; compound eyes with minute setae; preoccipital ridge carinate. Mesoscutum anterior border slightly acuminate. Inner metatibial spur pectinate, with four branches excluding apical portion of rachis. Forewing with $1 \mathrm{~m}-\mathrm{cu}$ confluent with $1 \mathrm{rs}-\mathrm{m}$; maximal length of third submarginal cell more than twice maximal length of second submarginal cell. Metapostnotum as long as mesoscutellum, broadly rounded posteriorly. Metasoma broadly rounded; terga not depressed; sterna unmodified.

Head punctate, punctures contiguous on upper parocular area, those punctures on frons stronger than elsewhere on face. Mesoscutum densely punctate, punctures irregular in diameter, contiguous around parapsidal lines and posteriorly, separated by less than a puncture width centrally, blending to strongly imbricate integument medioanteriorly. Mesepisternum densely punctate and rugulose. Metapostnotal striations longitudinal and partly irregular, striations covering entire surface, apically weaker and difficult to discern among strongly granular integument (Fig. 3). Metasomal terga lineolate with small puncures, those of tergum I smaller in diameter than those on other terga.

Integument of head and mesosoma brilliant metallic green with some cupreous reflections. Mandible, labrum, malar space, and apical one-half of clypeus dark brown; antenna, all leg podites, tegula, and sterna light brown. Wing veins brown; membrane lightly fuscous. Terga mostly brilliant metallic green with small brown areas on median surface of metasomal terga I and II, apical marginal areas translucent brown, abruptly demarcated from remainder of terga.

Pubescence on head, mesosoma, and sterna pale yellow, on legs dark amber, on terga light amber. Setae short on terga, long and erect on sterna; metasomal sternum II and III with long setae with recurved apices. 

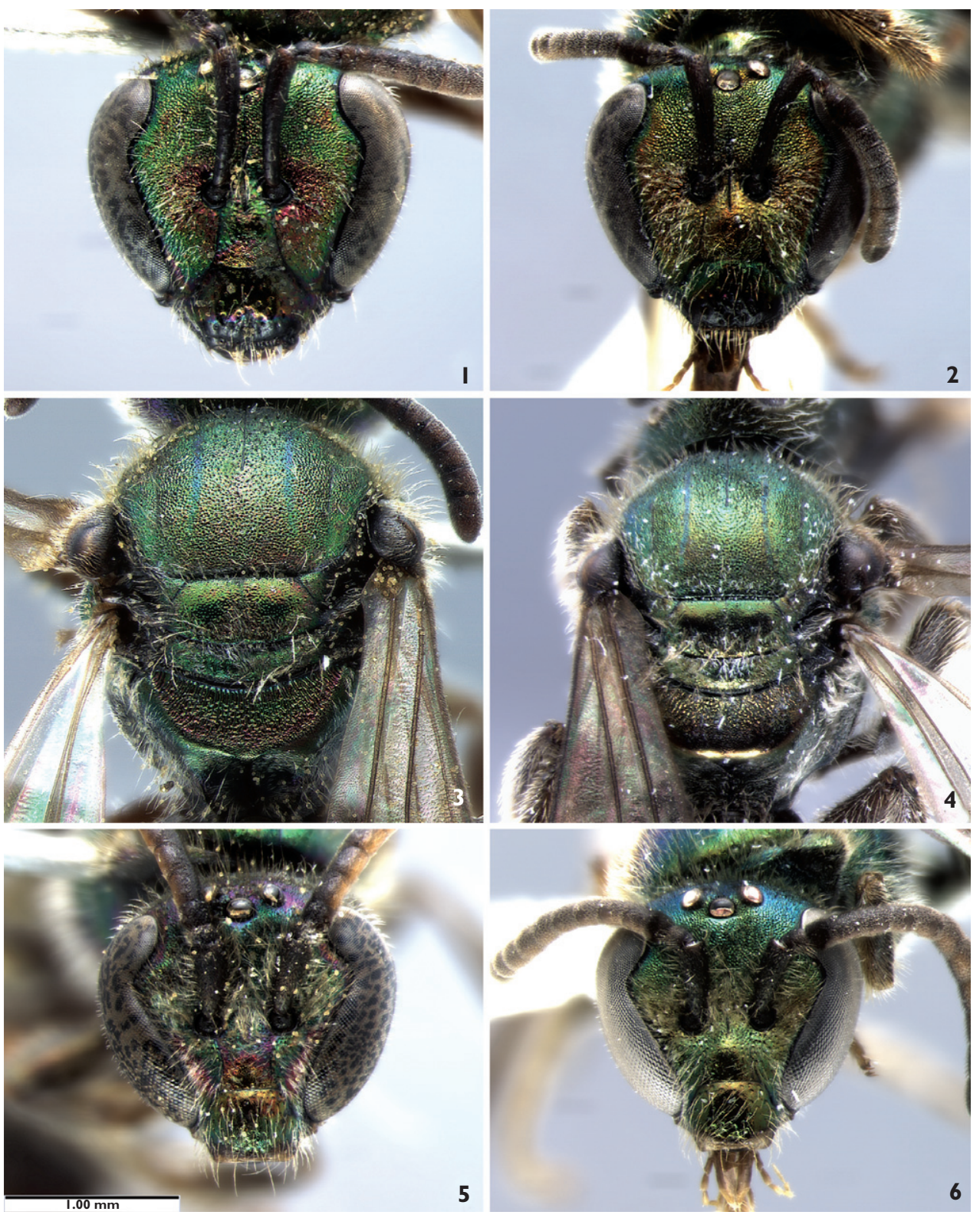

Figures I-6. Face and mesosoma of new species of Caenaugochlora (Caenaugochlora). I Facial aspect of Caenaugochlora $(C$.) bennetti, sp. n., female 2 Facial aspect of $C$. (C.) quichua, sp. n., female 3 Female mesosoma of $C$. (C.) bennetti, sp. n. 4 Female mesosoma of $C$. (C.) quichua, sp. n. 5 Facial aspect of $C$. (C.) bennetti, sp. n., male 6 Facial aspect of $C$. (C.) quichua, sp. n., male (scale bar $=1 \mathrm{~mm}$ ).

Male: as described for female except as follows: Total body length $6.0 \mathrm{~mm}$; forewing length $4.8 \mathrm{~mm}$; distance between compound eye notches $1.2 \mathrm{~mm}$; maximum head length $1.8 \mathrm{~mm}$; intertegular distance $1.1 \mathrm{~mm}$. Head longer than wide; not strongly 
depressed (Fig. 5). Mesoscutal median line well impressed. Metapostnotum as long as mesoscutellum, slightly depressed. Lateral projection of metasomal sternum IV as long as sternum length (Fig. 7); metasomal sternum VI strongly emarginate; metasomal sternum VII and VIII as depicted in Figure 9; genital capsule as depicted in Figure 11.

Clypeus and supraclypeal area with fewer punctures than lower parocular area, with imbricate microreticulations. Mesoscutum strongly punctate, punctures separated by less than a puncture width, integument between (where perceptible) with imbricate microreticulations. Metapostnotal striae dense, almost entirely longitudinal, extending along entire surface, weaker apically and difficult to discern among strongly granular integument. Terga irregularly punctuate and lineolate.

Integument of head and mesosoma brilliant metallic green with some dark reflections. Apical margin of clypeus narrowly pale amber. Coxae to femora with metallic highlights, tibiae and remaining podites dark amber. Metasoma entirely brown.

Pubescence on face long and plumose, especially above supraclypeal area. Lateral projection of metasomal sternum IV bearing four setae at apex, sternal apical margin with a central patch of setae (Fig. 7). Genital capsule as depicted in Figure 11.

Etymology. The specific epithet is a patronym honoring Mr. Daniel J. Bennett, leading student of the systematics of crabronine wasps.

\section{Caenaugochlora (Caenaugochlora) quichua, sp. n.}

urn:lsid:zoobank.org:act:749D7746-D785-4090-84E5-7EB5F00881F9

Figs 2, 4, 6, 8, 10, 12, 13

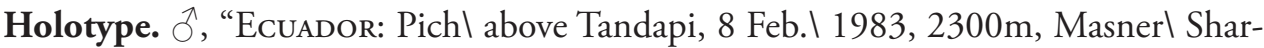
key" (SEMC).

Paratypes. $19,2 \hat{\jmath}$, with same label data as holotype (SEMC); $1 \hat{\jmath} q$, with same label data as holotype (MZSP); 1 $q$, "EcuAdor, Imbaura:\N. Perucho near $\backslash$ Otavalo, I-7-1971\} 2 0 0 0 \text { m., L. Pena” (SEMC). }

Diagnosis. Both sexes with preoccipital ridge carinate; female metabasitibial plate well rimmed; female metapostnotum with striations not reaching the posterior margin; male face concave above the antennal alveolus with a stripe of short, strongly plumose setae; medioapical margin of metasomal sternum III not notched; apical margin of metasomal sternum IV straight, subapical margin with pubescence distributed as on metasomal sternum III, lateral projections, including setae, as long as sternum.

Description. Female: Total body length $5.95 \mathrm{~mm}$; forewing length $4.6 \mathrm{~mm}$; distance between compound eye notches $1.17 \mathrm{~mm}$; maximum head length $1.55 \mathrm{~mm}$; intertegular distance $1.2 \mathrm{~mm}$. Head rounded (Fig. 2); mandible with weak subapical tooth; malar space very short, less than basal mandibular width; compound eyes with minute setae; preoccipital ridge carinate. Mesoscutum anterior border slightly acuminate. Inner metatibial spur pectinate, with three branches excluding apical portion of rachis. Forewing with $1 \mathrm{~m}$-cu confluent with $1 \mathrm{rs}-\mathrm{m}$; maximal length of third 

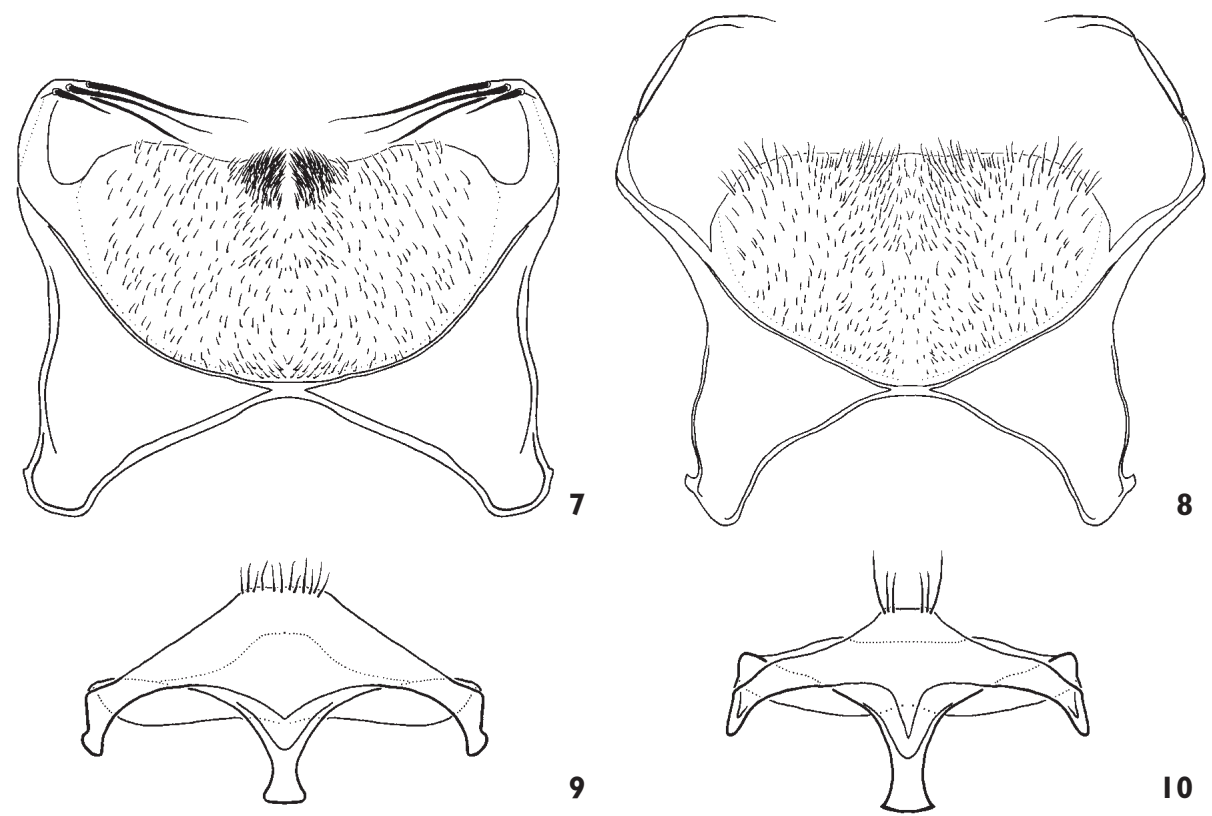

10

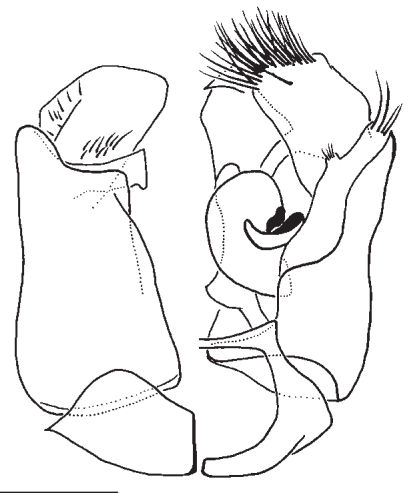

I I

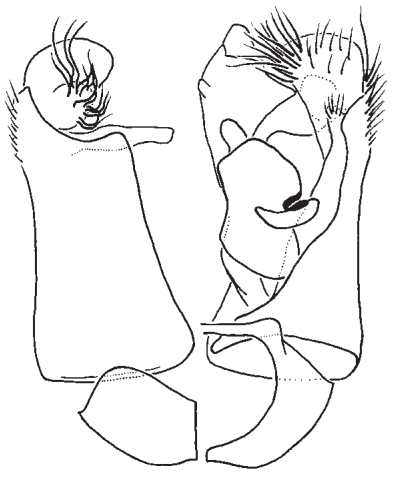

12

Figures 7-12. Male sterna and genital capsule of new species of Caenaugochlora (Caenaugochlora). $7 \mathrm{Me}-$ tasomal sternum IV of Caenaugochlora (C.) bennetti, sp. n. 8 Metasomal sternum IV of C. (C.) quichua, sp. n. 9 Metasomal sterna VII and VIII of $C$. (C.) bennetti, sp. n. 10 Metasomal sterna VII and VIII of $C$. (C.) quichua, sp. n. I I Genital capsule of $C$. (C.) bennetti, sp. n. I2 Genital capsule of $C$. (C.) quichua, sp. n. (scale bar $=0.5 \mathrm{~mm})$.

submarginal cell less than two times maximal length of second submarginal cell. Metapostnotum as long as mesoscutellum, broadly rounded posteriorly. Metasoma broadly rounded; terga not depressed; sterna unmodified.

Head punctate, punctures contiguous in upper parocular area and on frons, imbricate microreticulations evident. Mesoscutum granular, punctures irregularly distributed with microreticulations evident among punctures. Mesepisternum more granular than mesoscutum. Metapostnotal striations irregular, extending to two-thirds length, 
remainder of surface strongly imbricate (Fig. 4). Terga lineolate with small punctures, those on terga III-V with greater diameter.

Integument of head and mesosoma brilliant metallic green with some dull blue reflections. Mandible, labrum, malar space, and apical one-half of clypeus dark brown; antenna, all leg podites, tegula, and sterna light brown. Wing veins brown; membrane lightly fuscous. Terga mostly brilliant metallic green with some dark brown areas on median surface of discs, apical marginal areas blending to translucent brown.

Pubescence on head, mesosoma, and metasomal sterna pale yellow; setae on legs dark amber, on terga light amber; setae short on terga, long and erect on sterna; sternum II with long setae with recurved apices.

Male: as described for female except as following: Total body length $5.82 \mathrm{~mm}$; forewing length $4.4 \mathrm{~mm}$; distance between compound eye notches $1.1 \mathrm{~mm}$; maximum head length $1.62 \mathrm{~mm}$; intertegular distance $1.0 \mathrm{~mm}$. Head longer than wide (Fig. 6); surface between supraclypeal area and frons depressed. Mesoscutal median line well impressed. Metapostnotum longer than mesoscutellum, with depressed striate surface. Metasomal sternum IV with lateral projections longer than sternum length (Fig. 8); metasomal sternum VI strongly emarginate; metasomal sterna VII and VIII as depicted in Figure 10; genital capsule as depicted in Figure 12.

Clypeus and supraclypeal area with few punctures, without evident microreticulations. Mesoscutum sparsely punctate, punctures fine and separated by more than three times a puncture diameter. Metapostnotal striae mostly longitudinally oriented, forming a triangle of ornamentation, not reaching posterior border, especially at corners. Terga finely punctate.

Integument of head and mesosoma brilliant metallic green with some blue reflections. Apical border of clypeus yellow. Coxae to femora with metallic highlights, tibiae brown, remaining podites light brown. Metasoma entirely dark brown.

Depressed surface of head with short, dense, plumose setae. Projection of metasomal sternum IV bearing long setae, apical margin not bearing short specialized setae. Genital capsule pubescence as depicted in Figure 12.

Etymology. The specific epithet is a noun in apposition and honors the Native American language Quichua, still spoken today in the Andes.

\section{Subgenus Ctenaugochlora Eickwort}

Caenaugochlora (Ctenaugochlora) Eickwort, 1969: 435. Type species: Neocorynura perpectinata Michener, 1954, monobasic and original designation.

Diagnosis. Refer to the diagnosis for Caenaugochlora s.str. (vide supra).

Description. As for the genus with the following additions: Female: Compound eyes with minute setae. Preoccipital ridge carinate. Pronotal lateral angle not produced, obtuse. Metabasitibial plate bordered posteriorly, margin obsolete anteriorly; inner metatibial spur densely pectinate, with more than 10 long branches. Metapos- 


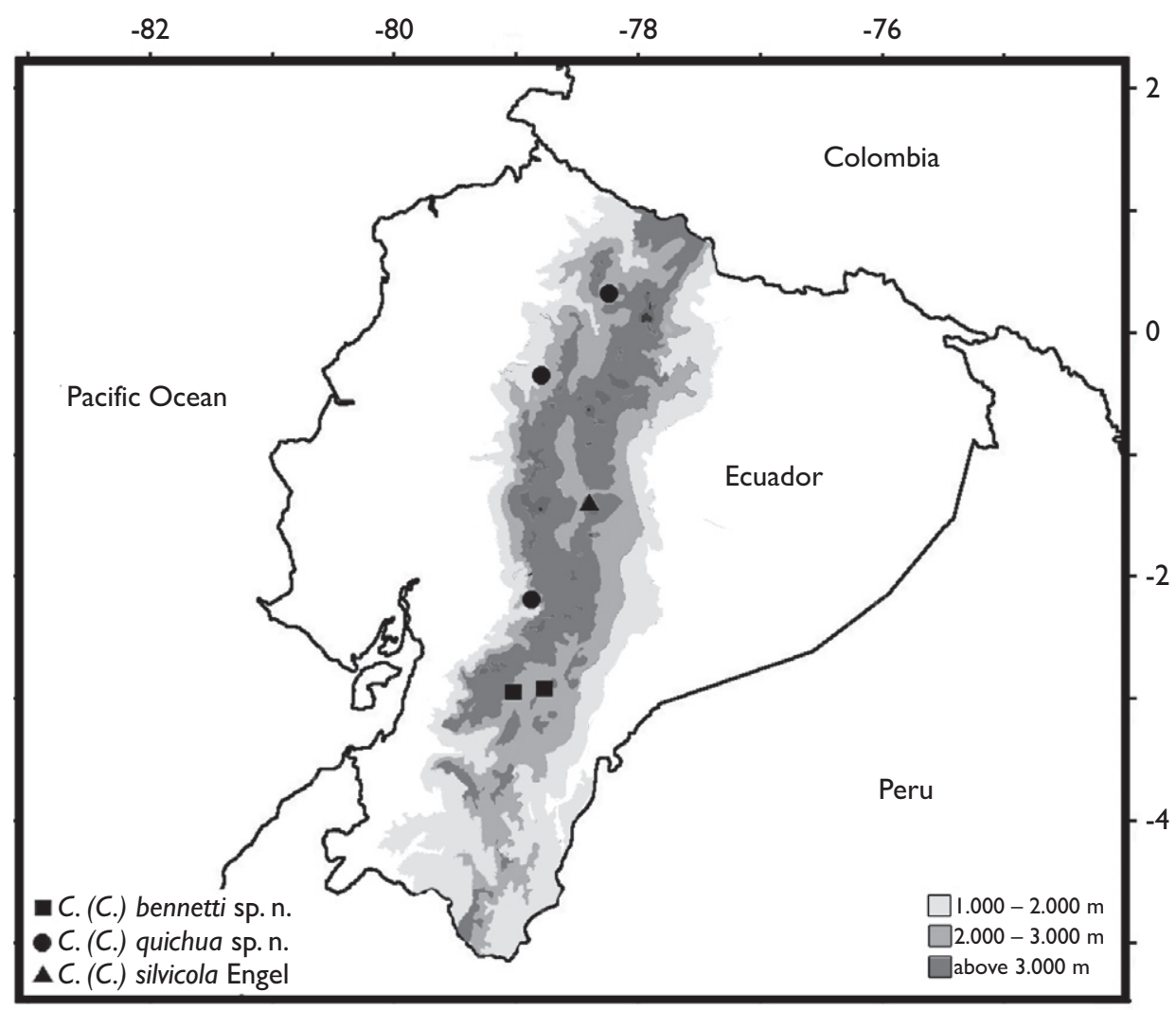

Figure 13. Distribution map of known Caenaugochlora s.str. from Ecuador.

tnotum with strong striae radiating from basal margin to apex. Male: Apical margin of metasomal sternum IV concave, with dense triangular setal patch, patch not raised on tubercles; apical margin of metasomal sternum VIII unmodified. Inner margin of volsella rounded.

Distribution. Species occur predominantly in Costa Rica and Panamá, with a single putative record from Bolivia (Engel and Gonçalves in press).

\section{Discussion}

Neither C. bennetti nor C. quichua fit precisely the description of either subgenus in Caenaugochlora. Both species are unique among the genus by combining setose compound eyes, a carinate preoccipital ridge, and male fourth metasomal sternal projections. As previously understood, the carinate preoccipital ridge is presently only in species of Ctenaugochlora, while in Caenaugochlora s.str. the ridge is distinctly sharply angled but not carinate. On the other hand the setose compound eyes and metapostnotal ornamentation (not radiating) are typical of Caenaugochlora s.str. The body shape and 
size is reminiscent of small Caenaugochlora s.str. such as C. gemmella and C. macswaini both from southern Central America. Lastly, the presence of a broad parapenial lobe and the lateral projections of the fourth metasomal sterna are unique among Caenaugochlora s.l. Both subgenera can have median patches of setae on the fourth metasomal sternum which are frequently associated with a median notch, while the third metasomal sternum is also frequently notched and bears setae. The distribution of characters may suggest that they are sister to Ctenaugochlora but they may also represent a basal branch of the genus. Rather than create a third subgenus we chose to alter the delimitation of Caenaugochlora s.str. to provisionally include these new species. Together these species may prove important for understanding the phylogeny of Caenaugochlora, particularly given that the lateral projections of the male fourth metasomal sterna are similar to those found in Augochloropsis Cockerell, Augochlorodes Moure, Neocorynura joannisi (Vachal) and Thectochlora Moure. These projections in Caenaugochlora are formed by sclerotized extensions of pregradular and postgradular areas as present in some Augochloropsis (vide Eickwort 1969: 468, Figs 243, 244). For species of Thectochlora, Augochlorodes turrifaciens Moure (Eickwort 1969: 469, Figs 248, 249) and $N$. joannisi (Smith-Pardo \& Gonzalez 2009: 120, Fig. 13) the projections are formed principally by extension of postgradular integument, while pregradular integument does not extend along the projection. This trait may favor Engel's (2000) cladistic hypothesis in which Augochloropsis s.l. and Caenaugochlora s.l. were sister taxa. Modifications of the male sterna, especially those on the fourth sternum, are common in halictines (Michener 2007) and such lateral projections can often be convergent. Further cladistic work is needed in order to more thoroughly evaluate the precise relationship of these new species and their implications for understanding affinities of Caenaugochlora s.l.

\section{Acknowledgements}

Partial support was provided by Fundação de Amparo à Pesquisa do Estado de São Paulo (FAPESP), Ph.D. Scholarship 07/01296-0 (to R.B.G.) and by U.S. National Science Foundation grant EF-0341724 (to M.S.E.). This is a contribution of the Division of Entomology, University of Kansas Natural History Museum.

\section{References}

Almeida EAB (2008) Revision of the Brazilian species of Pseudaugochlora Michener, 1954 (Hymenoptera: Halictidae: Augochlorini). Zootaxa 1678: 1-38.

Eickwort GC (1969) Tribal positions of Western Hemisphere green sweat bees, with comments on their nest architecture (Hymenoptera: Halictidae). Annals of the Entomological Society of America 62(3): 652-660.

Engel MS (1997) Two new species of the neotropical bee genus Caenaugochlora (s. str.) Michener (Insecta: Hymenoptera: Halictidae: Augochlorini). Reichenbachia 32(15): 91-95. 
Engel MS (2000) Classification of the bee tribe Augochlorini (Hymenoptera: Halictidae). Bulletin of the American Museum of Natural History 250: 1-89.

Engel MS (2001) A monograph of the Baltic amber bees and evolution of the Apoidea (Hymenoptera). Bulletin of the American Museum of Natural History 259: 1-192.

Engel MS (2007) Two new augochlorine bees from Ecuador (Hymenoptera: Halictidae). Acta Entomologica Slovenica 15(1): 21-29.

Engel MS (2009a) A new species of the bee genus Caenaugochlora from Honduras (Hymenoptera: Halictidae). Transactions of the Kansas Academy of Science 112(3-4): 159-163.

Engel MS (2009b) Revision of the bee genus Chlerogella (Hymenoptera, Halictidae), Part I: Central American species. ZooKeys 23: 47-75.

Engel MS, Gonçalves RB (in press) A revised key to the species of Caenaugochlora (Ctenaugochlora) (Hymenoptera: Apoidea: Augochlorini), with the description of a new species from Costa Rica. Genus.

Michener CD (1954) Bees of Panamá. Bulletin of the American Museum of Natural History 104(1): 1-176.

Michener CD (2007) The Bees of the World [2 $2^{\text {nd }}$ Edition]. Johns Hopkins University Press, Baltimore, xvi+[i]+953 pp.

Michener CD, Kerfoot WB (1967) Nests and social behavior of three species of Pseudaugochloropsis (Hymenoptera: Halictidae). Journal of the Kansas Entomological Society 40(2): 214-232.

Moure JS (2007) Augochlorini. In: Moure JS, Urban D, Melo GAR (Eds) Catalogue of Bees (Hymenoptera, Apoidea) in the Neotropical Region. Sociedade Brasileira de Entomologia, Curitiba, 677-691 [total volume pages xiv+1058 pp.].

Smith-Pardo A, Gonzalez, VH (2009) A revision of Neocorynura bees of the joannisi group with new geographical records for other Andean species (Hymenoptera: Halictidae, Augochlorini). Studies on Neotropical Fauna and Environment 44(2): 115-129. 